\title{
From the Congress Presidency
}

\section{Anatomist 2009, the 10 $^{\text {th }}$ Congress of EACA in Istanbul where the Continents Meet}

Anatomist 2009 , the $10^{\text {th }}$ Congress of EACA, hosted by the Turkish Society of Anatomy and Clinical Anatomy (TSACA), is a new step of the biennial EACA congresses successfully organized since 1991. With ever growing enthusiasm, this year's congress is going to be held in Istanbul with the participation of roughly 400 colleagues from 37 different countries. Istanbul, European Capital of Culture in 2010 is the only city uniting two continents with a very rich social and cultural heritage. Being endowed with different cultures and civilizations, ranging from the ancient Greek, Roman, and Ottoman Empires to the modern Republic of Turkey, it always played an important role as a city of peace in history. This time the anatomists and clinicians from almost all over the world will meet for exchanging their experience and ideas for scientific goals. While attending a high level congress, all participants will also have the chance to enjoy the history and the charm of Istanbul and Bosphorus. The scientific program covers most of the topics of anatomy applied to surgical and medical practice, from medical imaging and clinical neuroanatomy to new teaching tools and educational techniques. It consists of one panel, 3 symposia, 11 plenary lectures, 114 platform presentations and 366 poster presentations in 17 sessions most of which are parallel. One of the important features distinguishing the scientific program of this congress of EACA is that some of the sessions have been planned with the collaboration of the International Academy of Clinical Anatomy (IACA). IACA was established in 2007 with the founding members from different countries to promote teaching of clinical anatomy. So, the excellent program organized by the Scientific Committee, the colorful and exiciting social activities, coupled with the breath taking panorama and exotic surroundings of Istanbul will make Anatomist 2009 a rewarding educational and social travel experience. While concluding, we thank the Organizing Committee, which consists of the Executive Committee of Turkish Society of Anatomy and Clinical Anatomy (TSACA) and delegates from the anatomy departments of three medical faculties of Istanbul and Marmara Universities, for their non-stop efforts as well as our International Congress Coordinators, Dr. Andreas H. Weiglein from Graz, Austria and Dr. Stephen W. Carmichael from Rochester, MN, USA for their kind support.

Professor Salih Murat Akkin MD Honorary Congress President Vice-President of EACA

Professor Hakan Hamdi Celik MD PhD President of Congress President of TSACA

\section{From the Secretary General of EACA}

\section{The 10th Congress of European Association of Clinical Anatomy}

The 10th Congress of European Association of Clinical Anatomy will take place in Istanbul in September 2009.

Prof. Hakan Hamdi Celik as Congress President and Prof. Salih Murat Akkin as Honorary President and their team organized an interesting scientific program as well as an extremely attractive social program. Just Istanbul is an exciting scene because there is a bridging to Asia. This is a special sign that there do not exist any borders whether in sciences nor between scientists.

Since 1990 the EACA has been holding continuously their meetings in different European countries. During this time the congresses increased in their importance. This shows that clinical anatomy as a relatively young branch of anatomy is getting more and more important, both for education of medical students and for postgraduate education of physicians in different special fields.

As former president and long lasting Secretary General it is an honour to me to express my thanks to the Congress President and Honorary President and their team and I wish them a very successful congress.

Furthermore I wish all participants a fine, informative and unforgettable stay in Istanbul.

O.Univ.Prof.Dr.Dr.h.c. Friedrich Anderhuber Secretary General of EACA 